\title{
AKSIENAVORSING EN DIE LEWENSVATBAARHEIDSTUDIE; 'N BENADERING TOT SINVOLLE NAVORSING
}

\author{
Kmdt B.W. Smuts*
}

\section{INLEIDING}

Navorsing is 'n term wat dikwels verkeerdelik gebruik word. Die sogenaamde navorsing wat deur populêre tydskrifte uitgevoer of aangehaal word, is dikwels slegs 'n aanduiding van die behoeftes of opinies van die skrywer. Die foutiewe of ontoepaslike interpretasie van navorsingsresultate is ' $n$ ander bekende probleem wat tot wangebruik van die term navorsing lei. Hierdie verskynsel ontstaan omdat die totale proses van navorsing nie deur die skrywers self deurloop is nie. Die totale navorsingsproses begin by die keuse van 'n geskikte onderwerp en eindig by die implementering van resultate. Waar die keuse van ' $n$ onderwerp gegrond is op ' $n$ bestaande behoefte, is die implementering van resultate slegs die afronding van die proses. Die keuse van 'n geskikte onderwerp is derhalwe die belangrikste stap in die navorsingsproses, maar nie altyd eenvoudig nie, veral wanneer die navorser of student 'n voordelige bydrae tot 'n organisasie soos die SA Weermag wil maak. Die lewensvatbaarheidstudie bied egter die oplossing tot die keuseprobleem, terwyl aksienavorsing die totale navorsingsproses, op grond van deelname van alle betrokkenes, beklemtoon.

Navorsing kan hierbenewens in twee breë rigtings verdeel word. Basiese navorsing behels die ontwikkeling en toets van hipoteses oor aangeleenthede waarin die navorser belang stel en het nie noodwendig toepassingsmoontlikhede nie. Persoonlike belangstelling in 'n onderwerp is ook nie noodwendig in stap met die behoeftes van die organisasie waarin die persoon werksaam is nie. Toegepaste navorsing, hierteenoor, mik op die praktiese implementering van resultate in 'n werklike probleemsituasie (Bailey, 1982). Die lewensvatbaarheid en aksienavorsing vind dus aansluiting by die laasgenoemde rigting.

Die skrywer moes onlangs 'n keuse oor 'n onderwerp en metode van navorsing uitoefen met die oog op voltooiing van ' $n$ verhandeling/skripsie. Daar is besluit om ' $n$ aksienavorsingsmodel (Lewin 1951), met inbegrip van 'n lewens- vatbaarheidstudie, te volg. Die metode waarvolgens die vermelde lewensvatbaarheidstudie uitgevoer is, asook enkele gedagtes oor aksienavorsing word vervolgens bespreek.

\section{LEWENSVATBAARHEIDSTUDIE}

'n Lewensvatbaarheidstudie, soos inleidend aangetoon, word uitgevoer om 'n keuse van 'n geskikte navorsingsonderwerp te maak. Die keuse word gemaak op grond van 'n behoefte aan spesifieke navorsing wat gevolglik uitvoerbaarheid en implementeerbaarheid verseker.

Die navorsing onder bespreking val op die gebied van die sielkunde en derhalwe is Militêre Psigologiese Instituut (MPI) genader met ' $n$ versoek om aan te toon waar daar 'n behoefte aan navorsing bestaan. Aangesien die navorser aan die SA Lugmag verbonde is, het MBI ses tema's wat tans daar van belang is, verskaf:

(a) Die hantering van afwesigheid deur gesinne van lugbemannings.

(b) 'n Vergelykende studie oor die verhouding tussen vlieëniers en grondbemanning.

(c) Die selfbeskouing van navigators teenoor die selfbeskouing van vlieëniers; teenoor die selfbeskouing van vlieëniers en navigators teenoor die selfbeskouing van offisiere van ander indelings.

(d) Ouderdom en die persepsie van bevoegdhede by vlieëniers.

(e) Die selfbeskouing van aktiewe vlieëniers teenoor die selfbeskouing van vlieëniers wat, as gevolg van mediese of ander redes, nie meer aktief vlieg nie.

(f) Die sielkundige effek op en die aanpassing van leerlingvlieëniers wat nie vliegopleiding suksesvol deurloop nie.

Met die identifisering van temas was die lewensvatbaarheidstudie nog nie afgehandel nie. Nou moes daar bepaal word watter een van die ses temas die uiteindelike onderwerp vir navorsing sal wees. Aangesien die navorsing direk aan die SA Lugmag gekoppel is, is dit logies om die inset vanuit daardie oord te verkry. 
Op ' $n$ voorkeurblad is die ses temas gelys en elke lid van topbestuur is versoek om op sy eie die temas in orde van prioriteit te plaas. Die individuele prioritiseringsblaaie is daarna op ' $n$ enkele blad gekonsolideer:

\begin{tabular}{|c|c|c|c|c|c|c|}
\hline $\begin{array}{c}\text { Tema } \\
\text { Bestuurslede }\end{array}$ & Afwesigheid & $\begin{array}{c}\text { VInrs } \\
\text { Grondbeman }\end{array}$ & $\begin{array}{c}\text { Selfbe- } \\
\text { skouing }\end{array}$ & Ouderdom & Akt vlieg nie & Leerling vinr \\
\hline & $\mathrm{a}$ & $\mathrm{b}$ & $\mathrm{c}$ & $\mathrm{d}$ & $\mathrm{e}$ & $\mathrm{f}$ \\
\cline { 2 - 7 } 1 & 3 & 1 & 2 & 4 & 5 & 6 \\
2 & 3 & 4 & 6 & 5 & 2 & 1 \\
3 & 4 & 2 & 1 & 5 & 3 & 6 \\
4 & 1 & 3 & 6 & 4 & 5 & 2 \\
5 & 1 & 2 & 3 & 6 & 5 & 4 \\
6 & 3 & 1 & 2 & 5 & 4 & 6 \\
7 & 1 & 2 & 3 & 4 & 5 & 6 \\
8 & 1 & 2 & 4 & 3 & 5 & 6 \\
9 & 1 & 2 & 3 & 5 & 6 & 4 \\
10 & 1 & 2 & 3 & 5 & 6 & 4 \\
11 & 1 & 2 & 3 & 4 & 5 & 6 \\
12 & 6 & 4 & 5 & 3 & 1 & 2 \\
13 & 1 & 6 & 5 & 2 & 4 & 3 \\
14 & 1 & 2 & 3 & 5 & 4 & 6 \\
\hline Totaal & 28 & 35 & 49 & 60 & 60 & 62 \\
\hline
\end{tabular}

Tabel 1: Aanvanklike prioriteitstoekennings

Oënskynlik blyk dit dat die tema met die laagste totaal die hoogste prioriteit sal geniet. Dit is nie noodwendig die geval nie omdat standaard afwyking $(S)$ en die gemiddelde persentasie van die rekenkundige gemiddeldes $(\bar{X} \%)$ nie in berekening gebring is nie. Ten einde die faktore $S$ en $\bar{X} \%$ in ag te neem is daar soos volg te werk gegaan:

(a) Bereken die $\bar{X}$ (rekenkundige gemiddelde) van elke tema.

(b) Bereken die S (standaard afwyking) van elke tema. (c) Bereken die persentasie van elke tema. (Die totaal van die tema gedeel deur die groot totaal vermenigvuldig met honderd).

(d) Bereken die $\bar{X} \%$ (gemiddelde persentasie) van die temas. (Someer die persentasies van die temas en deel deur die aantal temas.)

(e) Skakel die data, deur middel van McCall se $T$ skaal of die Z skaal om na 'n vergelykbare skaal (Ferguson, 1981).

Nadat die verwerking soos hierbo gedoen is, is die volgende gegewens verkry:

\begin{tabular}{|c|c|c|c|c|c|c|}
\hline \multirow[t]{2}{*}{ Tema } & Afwesigheid & $\begin{array}{c}\text { Vlnrs } \\
\text { grondbeman }\end{array}$ & $\begin{array}{l}\text { Selfbe- } \\
\text { skouing }\end{array}$ & Leerling & Ouderdom & Akt vlieg nie \\
\hline & $a$ & $b$ & c & $d$ & e & $f$ \\
\hline Totaal & 28 & 35 & 49 & 62 & 60 & 60 \\
\hline $\bar{x}$ & 2 & 2,5 & 3,5 & 4,4 & 4,3 & 4,3 \\
\hline S & 1,57 & 1,34 & 1,5 & 1,82 & 1,06 & 1,43 \\
\hline$\%$ & 9,5 & 11,9 & 16,6 & 21,0 & 20,5 & $\begin{array}{c}20,5 \\
(x=16,65 \%\end{array}$ \\
\hline McCall & 4,5 & 14,6 & 49,7 & 73,9 & 86,3 & 86,3 \\
\hline Z Skaal & $-4,55$ & $-3,54$ & $-0,03$ & $+2,39$ & $+3,63$ & $+3,63$ \\
\hline
\end{tabular}

Tabel II: Hersiene prioriteitstoekenning. 
Die resultaat van die Z skaal of McCall se T skaal word gerangskik van klein na groot om die orde van belangrikheid te bepaal. Let daarop dat die volgorde van tabelle I en II verskil, $d$ en e albei met roupunte van 60 , is na omskakeling laer as $f$ met 'n roupunt van 62. Die gegewens is na topbestuur teruggevoer wat die tema "afwesigheid", op grond van die wetenskaplike bepaling van die prioriteit, vir navorsing goedgekeur het.

\section{AKSIE NAVORSING}

Aksienavorsing kan beskryf word as 'n intervensie in die funksionering van die ware wêreld met 'n ontleding van die effek van die intervensies (Halsey, 1972). Verdere aspekte van die benadering is dat dit:

(a) situasioneel is - normaalweg is aksienavorsing gemoeid met evaluering van ' $n$ probleem binne 'n spesifieke konteks, asook om die probleem binne daardie konteks op te los;

(b) deelname bewerkstellig - spanlede of staflede neem direk en of indirek deel aan die implementering van die navorsing;

(c) samewerking ontlok - navorsing en praktisyn werk saam aan die projek; en

(d) self evaluerend is - die program word voortdurend aangepas as gevolg van evalueringsnavorsing om die program optimaal te verbeter.

Stappe wat by aksienavorsing gevolg kan word is die volgende (Odendal):

- Identifiseer die behoefte (Lewensvatbaarheidstudie).

- Bespreking en onderhandeling (Uitvoerbaarheidstudie).

- Literatuuroorsig, hier word beskikbare oorsese en plaaslike literatuur bestudeer.

- Herdefiniëring van die probleem, na aanleiding van bevindings by die eerste drie stappe.

- Infrastruktuur nodig vir die uitvoering van die navorsingsproses.

- Keuse van die evalueringsprosedures, bv vraelyste, onderhoude of projektiewe tegnieke.
- Operasionale fase, wat hoofsaaklik bestaan uit data-insameling en verwerking.

- Ontleding van finale resultate, gevolgtrekkings, aanbevelings en implementering van resultate.

Nadat die resultate vir 'n tydperk implementeer is, behoort ' $n$ herevaluasie van die probleem plaas te vind. Hierdie herevaluering sal aandui of daar enige verbeteringe plaasgevind het, asook of verdere ingrepe nodig is.

\section{SLOTSOM}

Die uitvoer van 'n lewensvatbaarheidstudie kan op enige gebied met vrug toegepas word. Dit is terloops nie net die student op magister of doktorale vlak wat navorsing doen nie. Dit geld vir enige persoon wat op hoogte van bepaalde verskynsels, met inbegrip van sy werksgebied, wil kom. Die gebied is voorts ook nie tot 'n vakgebied soos sielkundge of ' $n$ instansie soos MPI beperk nie, maar kan enige dissipline, instelling of eenheid betrek. Die navorsing hoef nie deur lede self uitgevoer te word nie, maar daar kan ten minste vir die navorser 'n duidelike behoefte gestel word waar die afdelingshoof die behoefte by ondergeskiktes deur middel van 'n lewensvatbaarheidstudie bepaal het. Spesifiek vir studente hou 'n lewensvatbaarheidstudie die voordeel en versekering in dat sy navorsingsresultate geïmplementeer sal word en nie op 'n rak beland en hy/sy net die bevrediging van die verwerwing van die betrokke graad kry nie. Andersyds verhoed 'n lewensvatbaarheidstudie en aksienavorsing dat energie en tyd onnodiglik na kanale waar daar nie ' $n$ behoefte is nie, gekanaliseer word.

*Kmdt B.W. Smuts Intern M.A. voorligting sielkunde 1 Mil Hospitaal

\section{BRONNELYS}

Bailey, K.D. (1982) Methods of social research. The Free Press: London. Ferguson, G.A. (1981) Statistical analysis in psychology and education. McGraw-Hill: Johannesburg.

Halsey, A.H (1972) Educational priority, 1, HMSO: London.

Lewin, K. (1951) Field theory in social science. Harper \& Row: New York. Odendal, A.W. Goalmanagement as an attempt to evaluate nature conservation campaigns. Ongepubliseerde artikel: Universiteit van Pretoria. 